\title{
SYNTHESIS AND LEISHMANICIDAL ACTIVITY OF NEW BIS-ALKYLQUINOLINES
}

\author{
WILSON CARDONA ${ }^{1 *}$, VICTOR ARANGO ${ }^{1}$, JORGE J. DOMÍNGUEZ ${ }^{1}$, SARA M. ROBLEDO ${ }^{2,3}$, DIANA L. \\ MUÑOZ ${ }^{2}$ BRUNO FIGADERE ${ }^{4}$, IVAN D. VELEZ ${ }^{2,3}$, JAIRO SÁEZ ${ }^{1}$
}

\author{
${ }^{1}$ Instituto de Química, Química de Plantas Colombianas, Universidad de Antioquia, A.A 1226, Medellín, Colombia. \\ ${ }^{2}$ PECET-Program for Study and Control of Tropical Diseases, Universidad de Antioquia, A.A 1226, Medellín, Colombia. \\ ${ }^{3}$ CIDEPRO-Center for Development of Products against Tropical Diseases, Medellin, Colombia. \\ ${ }^{4}$ Laboratoire de Pharmacognosie, Associe' au CNRS (BIOCIS), Universite' de Paris-Sud, \\ F-92296, Chatenay-Malabry, France
}

(Received: August 6, 2012 - Accepted: March 9, 2013)

\begin{abstract}
Bis-alkylquinolines 1-6 were synthetized via Williamson reaction between 8 -hydroxyquinaldine with different 1, $\omega$-dihaloalkanes. Structures of all the products were elucidated by spectroscopic analysis. Cytotoxic and antileishmanial activities of synthesized compounds were determinated on U-937 cells and L. (V) panamensis amastigotes, respectively. Compound 5, 1,9-bis[(2-methylquinolin-8-yl)oxy]nonane, was the most selective against axenic and intracellular amastigotes $\left(\mathrm{EC}_{50}=11.3\right.$ and $22.6, \mu \mathrm{g} / \mathrm{mL}$ ), with selectivity indices greater than 17.7 and 8.8 , respectively; which makes this compound promising for the developing of new leishmanicidal drugs.
\end{abstract}

Keywords: Leishmania, antiprotozoal, quinoline.

\section{INTRODUCTION}

Leishmaniasis is one of the world's most neglected diseases, affecting largely the poorest of the poor, mainly in developing countries; 350 million people are considered at risk of contracting leishmaniasis, and around 2 million new cases occur yearly ${ }^{1}$ and $\mathrm{WHO}$ has classified leishmaniasis as a category 1 disease, i.e. emerging and uncontrolled ${ }^{2}$.

Chemotherapy of leishmaniasis has been based on the pentavalent antimonials, sodium stibogluconate (Pentostam ${ }^{\circledR}$ ) and meglumine antimonite $\left(\right.$ Glucantime $\left.^{\circledR}\right)$. These drugs contain multiple uncharacterized molecular structures with variable efficacies, toxicities, possess severe side effects ${ }^{3,4}$ prone to induce resistance ${ }^{5-7}$ and require lengthy treatments with parenteral administration under medical supervision ${ }^{8}$. Second-line drugs, such as Amphotericin B and its lipid formulations are either too toxic or expensive for routine use in developing countries. For these reasons, it is necessary to develop new, efficient, non-toxic and cheaper drugs for the treatment of this disease.

The quinolinic core is a structural feature of many bioactive compounds. Among the biological activities exhibited by compounds having this heteroaromatic ring are cytotoxic ${ }^{9}$, antimalarial ${ }^{10}$, antituberculosis ${ }^{11}$, antimicrobia ${ }^{12}$, anti-HIV ${ }^{13}$, antiinflamatory ${ }^{14}$ and antioxidant ${ }^{15}$ activities. Some of these compounds showed antiprotozoal activity ${ }^{16,17}$ including leishmanicidal activity ${ }^{18-24}$.

Recently, four bis-quinolinoxyalkanes were examined against Leishmania donovani ${ }^{25}$ the causative agent of Visceral Leishmaniasis. Based on these results, we investigated other compounds of this series in search of novel antileishmanial compounds against Leishmania panamensis that causes cutaneous leishmaniasis and, to establish a possible structure-activity relationship. Three new bis-alkylquinolines were synthesized via Williamson etherification using 1, $\omega$-dihaloalkanes and 8-hydroxyquinaldine and cytotoxic and leishmanicidal activities of these compounds as three of the reported compounds, were screened in vitro against U-937 cells and L. (Viannia) panamensis, respectively.

\section{EXPERIMENTAL}

\section{Chemistry}

IR spectra were recorded on a Perkin-Elmer Spectrum RX I FT-IR system in a $\mathrm{KBr}$ disk. ${ }^{1} \mathrm{H}$ NMR and ${ }^{13} \mathrm{C}$ NMR spectra were recorded on Bruker 300 $\mathrm{MHz}$ spectrometer using $\mathrm{CDCl}_{3}$ as solvent and TMS as an internal standard. The chemical shifts are expressed in $\delta \mathrm{ppm}$. HRMS were run on a Xevo Q-Tof Waters mass spectrometer. Silica gel 60 (Merck ${ }^{\circledR} 0.063-0.200$ mesh) was used for column chromatography, and precoated silica gel plates (Merck® 60 F254 $0.2 \mathrm{~mm}$ ) were used for thin layer chromatography (TLC).
General method of synthesis of bis-alkylquinolines

To a solution of 2-methyl-8-hydroxyquinoline $(1.60 \mathrm{~g}, 10 \mathrm{mmol})$ in dichloromethane $(40 \mathrm{ml})$ was added aqueous $\mathrm{NaOH}$ solution $(10 \%, 50 \mathrm{ml})$ followed by the addition of $1 \mathrm{mmol}$ of tetrabutyl ammonium bromide and $10 \mathrm{mmol}$ of 1, $\omega$-dibromoalkane derivative. The mixture was stirred at room temperature for $24-48 \mathrm{~h}$, then the organic layer was isolated using a separating funnel, washed with water to remove alkali, dried over anhydrous magnesium sulfate, filtered and evaporated to dryness under reduced pressure. Column chromatography on silica gel (hexane-ethyl acetate) afford the expected bisalkylquinoline in yields ranging between 15 and $22 \%$ and the corresponding monoethers in yields between 25 and $47 \%$ (figure 1 ).

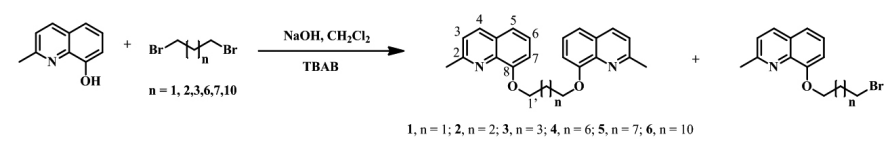

Figure 1. Synthetic path to obtain the bisalkylquinolines.

1,8-Bis[(2-methylquinolin-8-yl)oxy]octane, 4, Amorphous brown solid, m.p. $=91-93^{\circ} \mathrm{C}, 20 \%$ yield. IR cm${ }^{-1}: 2993,1602,1561,1104,761 .{ }^{1} \mathrm{H}$ NMR $\left(300 \mathrm{MHz}, \mathrm{CDCl}_{3}\right): \delta 2.73\left(\mathrm{~s}, 6 \mathrm{H} 2 \mathrm{CH}_{3}\right), 7.24(\mathrm{~d}, 2 \mathrm{H}, J=8.4 \mathrm{~Hz}, 2 \mathrm{H}-3), 7.95$ $(\mathrm{d}, 2 \mathrm{H}, J=8.4 \mathrm{~Hz}, 2 \mathrm{H}-4), 7.30(\mathrm{~d}, 2 \mathrm{H}, J=7.4 \mathrm{~Hz}, 2 \mathrm{H}-5), 7.33(\mathrm{t}, 2 \mathrm{H}, J=7.4$ $\mathrm{Hz}, 2 \mathrm{H}-6), 7.0$ (dd, $2 \mathrm{H}, J=7.0,1.8 \mathrm{~Hz}, 2 \mathrm{H}-7), 4.18\left(\mathrm{t}, 4 \mathrm{H}, J=7.2 \mathrm{~Hz}, \mathrm{H}-1^{\prime}\right.$, H-8'), 2.01 (q 4H, $\left.J=7.1 \mathrm{~Hz}, \mathrm{H}-2^{\prime}, \mathrm{H}^{-7} 7^{\prime}\right), 1.51$ (m, 4H, H-3', H-6'), 1.48 (m, $\mathrm{H}-4$ ', $\mathrm{H}-5$ '). ${ }^{13} \mathrm{C}$ NMR $\left(75 \mathrm{MHz}, \mathrm{CDCl}_{3}\right): \boldsymbol{\delta} 25.6\left(2 \mathrm{CH}_{3}\right), 154.2(2 \mathrm{C}-2), 122.3$ (2 C-3), 135.9 (2 C-4), 127.6 (2 C-4a), 119.1 (2 C-5), 125.5 (2 C-6), 108.9 (2 C-7), 157.9 (2 C-8), 68.9 (C-1'), 28.7 (C-2'), 25.8 (C-3'), 29.2 (C-4'), 29.2 (C-5'), 25.8 (C-6'), 28.7 (C-7'), 68.9 (C-8'). APCI MS $m / z$ 429.2562 [M+ H].

1,9-Bis[(2-methylquinolin-8-yl)oxy]nonane, 5, Amorphous yellow solid, m.p. $=110-112^{\circ} \mathrm{C}, 22 \%$ yield. IR cm${ }^{-1}: 1654,1605,1560,1431,1107,760 .{ }^{1} \mathrm{H}$ NMR (300MHz, $\left.\mathrm{CDCl}_{3}\right): \delta 2.72\left(\mathrm{~s}, 6 \mathrm{H}, 2 \mathrm{CH}_{3}\right), 7.27(\mathrm{~d}, 2 \mathrm{H}, J=8.4 \mathrm{~Hz}, 2 \mathrm{H}-3)$ $7.98(\mathrm{~d}, 2 \mathrm{H}, J=8.4 \mathrm{~Hz}, 2 \mathrm{H}-4), 7.35(\mathrm{~d}, 2 \mathrm{H}, J=7.0 \mathrm{~Hz}, 2 \mathrm{H}-5), 7.36(\mathrm{t}, 2 \mathrm{H}$, $J=7.4 \mathrm{~Hz}, 2 \mathrm{H}-6), 7.03$ (dd, $2 \mathrm{H}, J=7.0,1.8 \mathrm{~Hz}, 2 \mathrm{H}-7), 4.16$ (t, $4 \mathrm{H}, J=7.2$ Hz, H-1', H-9'), 1.97 (q, 4H, J = 7.2 Hz, H-2', H-8'), 1.47 (m, 8H, H-3', H-4', H-6', H-7'), 1.35 (m, 2H, H-5'). ${ }^{13} \mathrm{C}$ NMR (75MHz, $\left.\mathrm{CDCl}_{3}\right): \delta 25.6\left(2 \mathrm{CH}_{3}\right)$, 157.8 (2 C-2), 122.2 (2 C-3), 135.9 (2 C-4), 127.6 (2 C-4a), 119.1 (2 C-5), 125.5 (2 C-6), 108.9 (2 C-7), 154.2 (2 C-8), 68.9 (C-1'), 29.3 (C-2'), 25.9 (C3'), 28.7 (C-4'), 29.4 (C-5'), 28.7 (C-6'), 25.9 (C-7'), 29.3 (C-8'), 68.9 (C-9'). APCI MS $m / z 443.2710[\mathrm{M}+\mathrm{H}]^{+}$.

1,12-Bis[(2-methylquinolin-8-yl)oxy]dodecane, 6, Amorphous brown solid, m.p. $=153-155^{\circ} \mathrm{C}, 15 \%$ yield. $\mathrm{IR} \mathrm{cm}^{-1}: 1603,1562,1430,1260,1106$, 745. ${ }^{1} \mathrm{HNMR}\left(300 \mathrm{MHz}, \mathrm{CDCl}_{3}\right): \boldsymbol{\delta} 2.72\left(\mathrm{~s}, 6 \mathrm{H}, 2 \mathrm{CH}_{3}\right), 7.28(\mathrm{~d}, 2 \mathrm{H}, J=8.4 \mathrm{~Hz}$ $2 \mathrm{H}-3), 7.99$ (d, $2 \mathrm{H}, J=8.4 \mathrm{~Hz}, 2 \mathrm{H}-4), 7.23$ (d, 2H, $J=7.2 \mathrm{~Hz}, 2 \mathrm{H}-5), 7.37$ (t, $2 \mathrm{H}, J=7.2 \mathrm{~Hz}, 2 \mathrm{H}-6), 7.03$ (dd, 2H, $J=7.2,1.8 \mathrm{~Hz}, 2 \mathrm{H}-7), 4.16(\mathrm{t}, 4 \mathrm{H}, J=$ $7.3 \mathrm{~Hz}, \mathrm{H}-1$ ', H-12'), 1.97 (q, 4H, $J=7.3 \mathrm{~Hz}, \mathrm{H}-2$ ', $\mathrm{H}^{-11}$ '), 1.45 (m, 4H, H-3', $\left.\mathrm{H}-10^{\prime}\right), 1.30$ (m, 12H, H-4', H-5', H-6', H-7', H-8', H-9'). ${ }^{13} \mathrm{C}$ NMR (75MHz, 
$\left.\mathrm{CDCl}_{3}\right): \delta 25.7\left(2 \mathrm{CH}_{3}\right), 158.0$ (2 C-2), 122.4 (2 C-3), 136.0 (2 C-4), 127.6 (2 C-4a), 119.2 (2 C-5), 125.3 (2 C-6), 108.9 (2 C-7), 154.3 (2 C-8), 154.3 (2 C-8a), 69.1 (C-1'), 29.4 (C-2'), 25.9 (C-3'), 28.8 (C-4'), 29.5 (C-5'), 29.5 (C-6’), 29.5 (C-7'), 29.5 (C-8'), 28.8 (C-9'), 25.9 (C-10’), 29.4 (C-11'), 69.1 (C-12'). APCI MS $m / z$ 485.3193 [M + H]

\section{Biological activity assays}

The compounds were subjected to in vitro leishmanicidal activity on axenic and intracellular amastigotes of $L$. (V) panamensis and cytotoxic activity on mammalian cells.

\section{In vitro cytotoxic activity in mammalian cells}

The cytotoxic activity of compounds was assessed based on the viability of the human promonocytic cell line U937 (ATCC CRL-1593.2 ${ }^{\text {TM}}$ ) evaluated by the MTT (3-(4,5-dimethylthiazol-2-yl)-2,5-diphenyltetrazolium bromide) method $^{26}$. Briefly, cells were grown in 96 wells-cell culture dishes at a concentration of 100,000 cells $/ \mathrm{ml}$ in RPMI-1640 supplemented with $10 \%$ FBS and the corresponding concentration of the compounds, starting at 200 $\mathrm{mg} / \mathrm{ml}$ in duplicate. The cells were incubated at $37^{\circ} \mathrm{C}$ with $5 \% \mathrm{CO}_{2}$ for 72 hours in the presence of the compounds and then the effect was determined using MTT assay, incubating at $37^{\circ} \mathrm{C}$ for 3 hours. After 72 hours of incubation the effect of compounds was determined by measuring the activity of the mitochondrial dehydrogenase by adding $10 \mathrm{ml} /$ well of MTT solution $(0.5 \mathrm{mg} /$ $\mathrm{ml}$ ) and incubating at $37^{\circ} \mathrm{C}$ for 3 hours. The reaction was stopped by adding a $50 \%$ isopropanol solution with $10 \%$ sodium dodecyl sulfate for $30 \mathrm{~min}$. Cell viability was determined based on the quantity of formazan produced, which was measured with a Bio-Rad ELISA reader set at $570 \mathrm{~nm}$. As a viability test was used cultured cells in the absence of extracts, as cytotoxicity control was used Amphotericin B and meglumine antimoniate. The results are expressed as the lethal concentration $50\left(\mathrm{LC}_{50}\right)$ calculated by the Probit method ${ }^{27}$.

In vitro leishmanicidal activity on axenic and intracellular amastigotes

Axenic and intracellular amastigotes of GFP-transfected $L$. $(V)$ panamensis strain (MHOM/CO/87/UA140epir GFP) were used for the in vitro testing of leishmanicidal activity of the bis-alkylquinolines.

\section{Activity against axenic amastigotes}

The ability of the bis-alkylquinolines to kill axenic amastigotes of $L$. $(V)$ panamensis was determined based on the viability of the parasites evaluated by the MTT (3-(4,5-dimethylthiazol-2-yl)-2,5-diphenyltetrazolium bromide) method $^{28}$. In brief, parasites were cultivated in Schneider's medium $\mathrm{pH} 5.4$ supplemented with $20 \%$ heat inactivated FBS for 3 days at $32^{\circ} \mathrm{C}$. Afterwards they were harvested, washed and resuspended at $2 \times 10^{6}$ axenic amastigotes $/ \mathrm{ml}$ in fresh medium. Each well of a 96-well plate was seeded with $100 \mu$ of each parasite suspension (in duplicate) and $100 \mu \mathrm{l}$ of each concentration of the test compound, starting at $100 \mathrm{mg} / \mathrm{ml}$, was added. Plates were incubated at $32^{\circ} \mathrm{C}$. After 72 hours of incubation the effect of drugs was determined by adding 10 $\mathrm{ml} /$ well of MTT and incubating at $32^{\circ} \mathrm{C}$ for 3 hours. The reaction was stopped and the quantity of formazan produced was measured with a Bio-Rad ELISA reader set at $570 \mathrm{~nm}$. Parasites cultivated in the absence of the compound but maintained under the same conditions were used as controls for growth and viability. Parasites cultivated in the presence of anphotericin B and meglumine antimoniate were used as controls for leishmanicidal activity.

\section{Activity against intracellular amastigotes}

The effect of the bis-alkylquinolines against intracellular amastigotes of $L$. (V) panamensis was evaluated by flow cytometry using the methodology described by Varela et al. $(2009)^{29}$. Briefly, U937 cells were dispensed in 24 well plates at a concentration of 300,000 cells/well, which were treated with $1 \mu \mathrm{M}$ of Phorbol Myristate Acetate (PMA) for $48 \mathrm{~h}$ at $37^{\circ} \mathrm{C}$, after which they were infected with promastigotes of $L$. $(V$.) panamensis in stationary growth phase (day 5) in modified NNN medium, a proportion of 1:25 cell/parasite, after 3 hours of incubation at $34^{\circ} \mathrm{C}$ in $5 \% \mathrm{CO}_{2}$ non-internalized parasites were washed and incubated again at $34^{\circ} \mathrm{C}$ and $5 \% \mathrm{CO}_{2}$ to allow differentiation to amastigotes form. After 24 hours of incubation, the compounds with the appropriate dilution, not exceeding the $\mathrm{LC}_{50}$, were added. Infected and treated cells were maintained at $34^{\circ} \mathrm{C}$ and $5 \% \mathrm{CO}_{2}$ for 72 hours. The leishmanicidal effect was measured in a flow cytometer at $488 \mathrm{~nm}$ of excitation and 525 $\mathrm{nm}$ of emission and determined as described by Valera el al. (2009). The results are expressed as the Effective Concentration $50\left(\mathrm{EC}_{50}\right)$ calculated by the Probit statistical method. The data are the average of three independent experiments conducted in duplicate. Infected but untreated cells were used as control of viability. Additionally, infected cells exposed to amphotericin B and meglumine antimoniate were used as control for leishmanicidal activity. The Selectivity Index (SI) was calculated by dividing the cytotoxic activity between the leishmanicidal activity $\left(\mathrm{SI}=\mathrm{LC}_{50} / \mathrm{EC}_{50}\right)$.

\section{RESULTS AND DISCUSSION}

\section{Chemistry}

Compounds described in this report were prepared as outlined in Figure 1. Reaction of 8-hydroxy quinaldine and 1,w-dibromoalkanes in aqueous solution of $\mathrm{NaOH}$ and dichloromethane to synthesize (1,w-bis(2-methylquinolin-8yloxy)alkane), was carried out under phase transfer catalysts condition. Two tandem substitutions of bromide from bromoalkane by quinoline occurred in 15 to $22 \%$ yield and allowed the preparation of compounds 4-6 for the first time. Compounds 1-3 have been synthesized and their leishmanicidal activity against $L$. (L) donovani reported ${ }^{25}$. The novel compounds 4-6 were characterized by their spectral data (IR, EIMS, ${ }^{1} \mathrm{H}$ and ${ }^{13} \mathrm{C}$ NMR, see materials and methods).

\section{Leishmanicidal and cytotoxicity activity}

The leishmanicidal and cytotoxicity activity of synthetic compounds as well as glucantime and amphotericin B, which were used as control drugs, was evaluated following the method reported in the literature ${ }^{26-30}$. The results were expressed as $\mathrm{EC}_{50}$ and $\mathrm{LC}_{50}$ values of compounds and are shown in the tables 1 and 2.

Table 1: In vitro leishmanicidal activity against axenic amatigotes of $L .(V)$ panamensis and toxicity of bis-alkylquinolines.

\begin{tabular}{|c|c|c|c|c|}
\hline Compound & $\begin{array}{c}\text { Cytotoxicity } \\
\mathbf{U 9 3 7} \text { cells } \\
\mathbf{L C}_{\mathbf{5 0}}(\boldsymbol{\mu} \mathbf{g} / \mathbf{m l})^{\mathbf{a}}\end{array}$ & $\begin{array}{c}\text { Leishmanicidal Activity } \\
\mathbf{E C}_{\mathbf{5 0}}(\boldsymbol{\mu} \mathbf{g} / \mathbf{m l})^{\mathbf{b}}\end{array}$ & $\mathbf{S I}^{\mathbf{c}}$ & Comment $^{\mathbf{2}}$ \\
\hline $\mathbf{1}$ & $9.2 \pm 0.2$ & $8.5 \pm 1.4$ & 1.1 & Cytotoxic and active $^{\mathrm{d}}$ \\
\hline $\mathbf{2}$ & $3.3 \pm 0.9$ & $>100.0$ & $<0.03$ & Cytotoxic and no active $^{\text {Cytotoxic and active }}$ \\
\hline $\mathbf{3}$ & $4.2 \pm 0.2$ & $6.2 \pm 0.4$ & $>0.7$ & No cytotoxic and no active \\
\hline $\mathbf{4}$ & $>200.0$ & $>100.0$ & $>17.7$ & No cytotoxic and active \\
\hline $\mathbf{5}$ & $>200.0$ & $11.3 \pm 1.9$ & $>2.0$ & No cytotoxic and no active \\
\hline $\mathbf{8}$ & $>200.0$ & $>100.0$ & 2.9 & Cytotoxic and active \\
\hline quinoline & $7.6 \pm 0.2$ & $2.6 \pm 0.3$ & 776 & Cytotoxic and active \\
\hline $\begin{array}{c}\text { Amphotericin B } \\
\text { Mntimoniate }\end{array}$ & $38.8 \pm 2.2$ & $0.05 \pm 0.01$ & $>1.0$ & No cytotoxic and no active \\
\hline
\end{tabular}

${ }^{\mathrm{a}} \mathrm{LC}_{50}$ : Lethal Concentration 50; ${ }^{\mathrm{b}} \mathrm{EC}_{50}$ : Effective Concentration 50; ${ }^{\mathrm{c}} \mathrm{SI}$ : selectivity index: $\mathrm{LC}_{50} / \mathrm{EC}_{50}$; ${ }^{\mathrm{d}}$ Cytotoxicity: $\mathrm{LC}_{50}<100 \mathrm{mg} / \mathrm{ml}$ No Cytoxicity: $\mathrm{LC}_{50}$ $>200 \mathrm{mg} / \mathrm{ml}$; Active: $\mathrm{EC}_{50}<20 \mathrm{mg} / \mathrm{ml}$; Moderately Active: $\mathrm{ELC}_{50}<100 \mathrm{mg} / \mathrm{ml}$; No Active: $\mathrm{EC}_{50}>100 \mathrm{mg} / \mathrm{ml}$ 
The results show that compounds $\mathbf{1}, \mathbf{3}, \mathbf{5}$ (bisquinolines), are very active against axenic amastigotes of $L$. panamensis exhibiting an $\mathrm{EC}_{50} \leq 12.0 \mathrm{mg} /$ $\mathrm{ml}$ (Table 1). No leishmancidal activity was observed for the compounds $\mathbf{2}, \mathbf{4}$ and 6 with $\mathrm{EC}_{50}>100 \mu \mathrm{g} / \mathrm{ml}$ (Table 1). Regarding to the toxic activity against macrophages, the results showed a high toxicity level for the compounds 1, 2, 3 and the 8-hydroxy quinoline with a $\mathrm{LC}_{50}<10 \mu \mathrm{g} / \mathrm{ml}$ (Table 1). No apparent toxicity was observed for the compounds 4,5 and $\mathbf{6}$. The $\mathrm{LC}_{50}$ for these compounds was $>200 \mu \mathrm{g} / \mathrm{ml}$ (Table 1). The best Selectivity Index was observed for the compound 5 with value of $>17.7$.

The leishmanicidal activity against the intracellular forms of Leishmania parasites was also determined only for those compounds that showed low toxicity levels. (Table 2). Among these compounds, only the compound $\mathbf{5}$ showed leishmanicidal activity against the intracellular form with an $\mathrm{EC}_{50}$ of $22.6 \mathrm{mg} / \mathrm{ml}$. The compounds $\mathbf{4}$ and $\mathbf{6}$ showed no activity against intracellular amastigotes of $L$. (V) panamensis $\left(\mathrm{EC}_{50}>100 \mathrm{mg} / \mathrm{ml}\right.$ ) (Table 2).

Table 2: In vitro activity of bis-alkylquinolines against intracellular amatigotes of $L$. panamensis.

\begin{tabular}{|c|c|c|c|}
\hline Compound & $\begin{array}{c}\text { Leishmanicidal } \\
\text { Activity } \\
\mathbf{E C}_{\mathbf{5 0}}(\boldsymbol{\mu g} / \mathbf{m l})\end{array}$ & SI & Comment \\
\hline $\mathbf{4}$ & $>100.0$ & $>2.0$ & No Active \\
\hline $\mathbf{5}$ & $22.6 \pm 1.0$ & $>8.9$ & Active \\
\hline $\mathbf{6}$ & $>100.0$ & $>2.0$ & No Active \\
\hline Amphotericin B & $0.04 \pm 0.01$ & 970.0 & Active \\
\hline $\begin{array}{c}\text { Meglumine } \\
\text { antimoniate }\end{array}$ & $6.8+0.5$ & $>147.05$ & Active \\
\hline
\end{tabular}

All results together show that the compound $\mathbf{5}$ is apparently the most promising compound because it showed low toxic activity on mammalian cells with $\mathrm{LC}_{50}>200 \mathrm{mg} / \mathrm{ml}$ but high leishmanicidal activity against both axenic and intracellular amastigotes with $\mathrm{EC}_{50}$ values of 11.3 and $22.6 \mathrm{mg} /$ $\mathrm{ml}$, respectively (Table 1 and Table 2). On the other hand, compounds $\mathbf{1}$ and $\mathbf{3}$ showed high leishmanicidal activity against axenic amastigotes. Nevertheless, these compounds also showed high toxicity against mammalian cells $\left(\mathrm{CE}_{50}\right.$ and $\mathrm{CL}_{50}$ values $<10 \mathrm{mg} / \mathrm{ml}$ ). The compound 2, that was highly toxic, showed no leihsmnicidal activity on axenic amastigotes $\left(\mathrm{CE}_{50}>100 \mathrm{mg} / \mathrm{ml}\right.$ and $\mathrm{CL}_{50}$ $=3.3 \mathrm{mg} / \mathrm{ml}$ ). The leishmanicidal activity observed with these compounds is similar to that found by Palit et al (2009) on promastigotes and intracellular amastigotes of $L$. (L.) infantum, where compounds $\mathbf{1}, \mathbf{2}$ and $\mathbf{3}$ showed $\mathrm{EC}_{50}$ values of $13.5 \mathrm{mg} / \mathrm{ml}, 3.2 \mathrm{mg} / \mathrm{ml}$ and $2.8 \mathrm{mg} / \mathrm{ml}$ for promastigotes and $\mathrm{EC}_{50}^{50}$ values of $10 \mathrm{mg} / \mathrm{ml}, 2.7 \mathrm{mg} / \mathrm{ml}$ and $2.4 \mathrm{mg} / \mathrm{ml} \mathrm{for} \mathrm{intracellular} \mathrm{amastigotes,}$ respectively. In this paper, these same compounds showed a lower toxicity on marine peritoneal macrophages than $\mathrm{U} 937$ cells. This, the $\mathrm{CL}_{50}$ values on peritoneal macrophages were $>200 \mathrm{mg} / \mathrm{ml},>90 \mathrm{mg} / \mathrm{ml}$ and $>85 \mathrm{mg} / \mathrm{ml}$, for compounds $\mathbf{1}, \mathbf{2}$, and $\mathbf{3}$, respectively, in comparison to the toxicity observed on U937 cells where the $\mathrm{CL}_{50}$ values were $<10 \mathrm{mg} / \mathrm{ml}$. The differential sensitivity exhibited by cell lines and primary culture cells has been demonstrated ${ }^{30}$.

8-hydroxy quinoline showed activity against U937 cells and axenic amastigotes of $L .(V)$ panamensis. Because of their high toxicity level, the activity of this compound against intracellular amastigotes was not determined. The dimer $\mathbf{5}$ was the least toxic compound showing high leishmanicidal activity for both axenic and intracellular amastigotes of $L$. (V) panamensis. In addition, some bisquinolines showed good activity and a low selectivity index.

Many quinolones have shown to be highly potent against protozoan parasites such as Plasmodium and Toxoplasma but also Leishmania ${ }^{31}$. Specifically furoquinolines, indolylquinolines and alkylquinolines have shown in vitro and/or in vivo leishmanicidal activity ${ }^{32-34}$. In these types of compounds the substituents may change the electronic structure of the molecule and in the case of alkyl group its hydrophilicity.

The analysis of the relationship between the leishmanicidal activity and structural factors suggest that the alkyl group gives a higher hydrophobicity to the molecules making them less soluble in aqueous systems but facilitating the cell membrane penetration. The biological activity in these alkyl quinolines is presented only when the ether bridge has an odd number of carbon atoms.

Although the mechanism of action of quinolone type compounds is unknown or not completely understood, several quinolones (e.g fluoroquinolones), can inhibit DNA replication by interacting with DNA gyrase and topoisomerase $\mathrm{IV}^{35}$, two essential bacterial type II topoisomerases present in Leishmania ${ }^{36}$ and other protozoal parasites; the stabilization of cleavable complexes by these inhibitors can lead to cell death through different pathways including activated kinases and death receptor pathways and caspase mediated cleavages ${ }^{37,38}$. Other quinolones such as sitamaquine (8-amino-quinoline) may induce structural alterations in intracellular Leishmania parasites ${ }^{39}$, leads to collapse of the mitochondrial inner membrane potential of Leishmania promastigotes ${ }^{40}$ or induce the alkalinization of the acidocalcisomes in Leishmania parasites ${ }^{41}$.

\section{CONCLUSION}

The results obtained are very promising since one of these compounds has potential as a leishmanicidal drug. Due to the high leishmanicidal activity and low cytotoxicity we consider that compound $\mathbf{5}$ is a good candidate and therefore preclinical studies on the animal model for cutaneous and visceral leishmaniasis disease should be done to confirm the results observed in vitro. On the other hand, compounds $\mathbf{1 , 3}$ and 8-hydroxyquinoline that were active against Leishmania parasite but toxic for mammalian cells. Although more studies on toxicity using other cell lines are needed in order to discriminate whether the toxicity showed by these compounds is selective against tumoral or non-tumoral cells. These molecules may be promising candidates to develop antileishmanial drugs by modifying their toxicity with bioguided studies. The mechanism of action of this promising compounds also need to be addressed.

\section{ACKNOWLEDGMENT}

We thank Blandine Séon-Méniel NMR measurements. This research was supported financially by Universidad de Antioquia (Programa de Sostenibilidad 2013 - 2014 and CIDEPRO).

\section{REFERENCES}

1. HW. Murray, JD. Berman, CR. Davies, NG. Saravia, Lancet, 366, 1561, (2005).

2. WHO, http://whqlibdoc.who.int/trs/WHO TRS 949 eng.pdf, (2010).

3. P. Desjeux, Comp. Immunol. Microbiol. Infect. Dis., 27, 305, (2004).

4. M. Ouellette, J. Drummelsmith, B. Papadopoulou, Drug Resist. Updat., 7, 257, (2004).

5. S.L. Croft, G. H. Coombs, Trends Parasitol., 19, 502, (2003).

6. F. Faraut-Gambarelli, R. Piarroux, M. Deniau, B. Giusiano, P. Marty, G. Michel, B. Faugere, H. Dumon, Antimicrob. Agents Chemother., 41, 827, (1997).

7. J.C. Antoine, C. Jouanne, A. Ryter, Parasitol. 99,1, (1989).

8. P.L. Olliaro, A.D. Bryceson, Parasitol. Today, 9, 323, (1993).

9. H. Zhang, V. R. Solomon, C. Hu, G. Ulibarri, H. Lee, Biomed. Pharm., 62, 65, (2008)

10. N. Sunduru, K. Srivastava, S. Rajakumar, S.K. Puri, J.K. Saxena, M.S. Chauhan, Bioorg Med Chem Lett., 19, 2570, (2009).

11. S. Eswaran, A.V. Adhikari, I.H. Chowdhury, D. Thomas, Eur. J. Med. Chem., 45, 3374, (2010)

12. K.D. Thomas, A.V. Adhikari, S. Shetty, Eur. J. Med. Chem., 45, 3803, (2010).

13. D. Narsinh, S. Anamik, Ind. J. Pharm. Sci., 63, 211, (2001).

14. R. D. Dillard, D. E. Pavey, D. N. Benslay, J. Med. Chem., 16, 251, (1973).

15. R. Subashini, S. Mohana Roopan, F. Nawaz Khan, J. Chil. Chem. Soc, $\mathbf{5 5}, 317,(2010)$.

16. G.C. Muscia, M. Bollini, A.M. Bruno, S.E. Asís, J. Chil. Chem. Soc., 51, $859,(2006)$

17. B. Akendengue, E. Ngou-Milama, A. Laurens, R. Hocquemiller, Parasite, 6, 3, (1999).

18. H. Nakayama, P.M. Loiseau, C. Bories, S.T. De Ortiz, A. Schinini, E. Serna, et. al., Antimicrob. Agents Chemother., 49, 4950, (2005).

19. A. Tempone, A. Melo, P. Da Silva, C. Brandt, F. Martinez, A. Borborema, Antimicrob. agents chemother., 49,1076, (2005).

20. R. Dietze, S. F. Carvalho, L. C. Valli, J. Berman, T. Brewer, W. Milhous, J. Sanchez, B. Schuster, M, Grogl, Am. J. Trop. Med. Hyg., 65, 685, (2001).

21. A.F. Mohammed, A. Fournet, E. Prina, J.F. Mouscadet, X. Franck, R. Hocquemiller, B. Figadere, M.A. Fakhfakh, Bioorg. Med. Chem. 11, 5013, (2003). 
22. J. Dade, O. Provot, H. Moskowitz, J. Mayrargue, E. Prina, Chem. Pharm. Bull., 49, 480, (2001).

23. A. Fournet, M.E. Ferreira, A.R.D. Arias, S.T. De Ortiz, S. Fuentes, H. Nakayama, A. Schinini, R. Hocquemiller, Antimicrob. Agents Chemother., 40, 2447, (1996).

24. N.C. Vieira, C. Herrenknecht, J. Vacus, A. Fournet, C. Bories, B. Figadere, et al., Biomed. Pharmac., 62, 684, (2008).

25. P. Palit, P. Paira, A. Hazra, S. Banerjee, A.D. Gupta, S. Dastidar, N. Mondal, Eur. J. Med. Chem., 44, 845, (2009).

26. S. Robledo, E. Osorio, L. Jaramillo, Antimic. Agents Chemoth., 49, 1652, (2005).

27. Finney JD Probit analysis, 3rd ed. Cambridge University Press, Cambridge, 1971

28. VM. Taylor, DL. Muñoz, DL. Cedeño, ID. Vélez, MA. Jones, SM, Robledo, Exp. Parasitol., 126, 471, (2010).

29. MR. Varela, DL. Muñoz, SM. Robledo, BK. Kolli, S. Dutta, KP. Chang, C. Muskus, Exp. Parasitol., 122, 134, (2009).

30. C. Mesa, D. Munoz, M. Echeverry, I. Velez, S. Robledo, Salud UIS, 42, 200, (2010)
31. G. Anquetin, J, Greiner, P. Vierling, Curr Drug Targets Infect Disord., 5, 227, (2005).

32. M. E. Ferreira, A. Rojas, G. Yaluff, N. Vera, H. Nakayama, S. Torres, A. Schinini, I. Guyc, H. Heinzen, A. Fournet, Phytomedicine, 17, 375 (2010).

33. G. Chakrabartia, A. Basu $a$, P. Pratim, S. Bhusahan, N. Bikash, S. Bandyopadhyay, J Antimicrob Chemother., 43, 359 (1999).

34. M. Fakhfakh, A. Fournet, E. Prina, J.F. Mouscadet, X. Franck, R. Hocquemiller, B. Figadere, Bioorg Med Chem., 11, 5013 (2003).

35. T. Cortázar, G. Coombs, J. Walker, Exp Parasitol., 116, 475 (2007).

36. A. Lucumi, S. Robledo, V. Gama, N. Saravia, Antimicrob Agents Chemother., 42, 1990 (1998)

37. S.H. Kaufmann, Biochim Biophys Acta 1400, 195 (1998).

38. K. Drlica, R.J. Franco, Biochemistry, 27, 2252 (1988).

39. S.G. Langreth, J.D. Berman, G.P. Riordan, L.S. Lee, J Protozool., 30 , $555,(1983)$.

40. A.E. Vercesi, R. Docampo, Biochem J., 284 (Pt 2), 463, (1992)

41. A.E. Vercesi, C.O. Rodrigues, R. Catisti , R. Docampo, FEBS Lett.,473, $203,(2000)$. 